\title{
Comparative analysis of spermiogenesis and sperm ultrastructure in Callich- thyidae (Teleostei: Ostariophysi: Siluriformes)
}

\author{
Maria A. Spadella*, Claudio Oliveira** and Irani Quagio-Grassiotto**
}

In Corydoradinae, the presence of spermatids in the lumen of the testicular tubules together with spermatozoa suggests that spermatogenesis is of the semicystic type, whereas in Callichthyinae, sperm production occurs entirely within spermatocysts in the germinal epithelium, characterizing cystic spermatogenesis. Spermiogenesis in Callichthyinae is characterized by an initial lateral development of the flagellum, the presence of nuclear rotation to different degrees, an eccentric or medial formation of a nuclear fossa, formation of a cytoplasmic channel, and presence of centriolar migration, being more similar to type I spermiogenesis. In Corydoradinae, spermiogenesis is characterized by eccentric development of the flagellum, the absence of nuclear rotation, an eccentric nuclear fossa formation, formation of a cytoplasmic channel, and absence of centriolar migration, differing from the types previously described. The process of spermatogenesis and spermiogenesis in Corydoradinae and Callichthyinae revealed unique characters for each of these subfamilies, corroborating the hypotheses that they constitute monophyletic groups. In relation to sperm ultrastructure, the comparative analysis of the callichthyid species shows that the general characteristics found in the spermatozoa were similar, thus, reinforcing the hypothesis that the family is monophyletic.

Em Corydoradinae, a presença de espermátides junto com espermatozóides no lúmen dos túbulos testiculares sugere uma espermatogênese do tipo semicística, enquanto que em Callichthyinae a produção do esperma ocorre inteiramente dentro dos espermatocistos no epitélio germinativo, caracterizando a espermatogênese cística. A espermiogênese em Callichthyinae é caracterizada por um desenvolvimento inicial lateral do flagelo, pela presença de rotação nuclear em diferentes graus, formação de uma fossa nuclear excêntrica ou medial, formação de um canal citoplasmático, e presença de migração centriolar, sendo mais similar à espermiogênese do tipo I. Em Corydoradinae, a espermiogênese é caracterizada pelo desenvolvimento excêntrico do flagelo, ausência de rotação nuclear, fossa nuclear excêntrica, formação de um canal citoplasmático, e ausência de migração centriolar, diferindo dos tipos descritos previamente. O processo de espermatogênese e espermiogênese em Corydoradinae e Callichthyinae revelaram caracteres únicos para cada subfamília, corroborando a hipótese de que as mesmas constituem grupos monofiléticos. Em relação à ultraestrutura do esperma, a análise comparativa das espécies de Callichthyidae mostra que as características gerais encontradas nos espermatozóides foram similares, reforçando a hipótese de monofilia da família.

Key words: Catfish, Spermatid, Spermatozoa, Phylogeny, Morphology.

\section{Introduction}

Siluriformes comprise an extremely large fish group that is widely distributed across the tropical regions of the world (Teugels, 1996). Among the Neotropical siluriform lineages likely to be monophyletic we find the superfamily Loricarioidea that comprises six families: Nematogenyidae, Trichomycteridae, Callichthyidae, Scoloplacidae, Astroblepidae, and Loricariidae (de Pinna, 1998; Britto, 2003a).

Callichthyidae form a well-corroborated monophyletic group, being one of the more speciose families of Loricarioidea, with approximately 180 valid species (Reis, 1998, 2003). Pres- ently, callichthyids are divided into two subfamilies, Corydoradinae and Callichthyinae, both monophyletic based on morphological and molecular characters (Reis, 1998, 2003; Britto, 2003b; Shimabukuro-Dias et al., 2004). Corydoradinae includes the genera Aspidoras, Scleromystax, and Corydoras and Callichthyinae includes Dianema, Hoplosternum, Megalechis, Lepthoplosternum, and Callichthys (Reis, 2003; Britto, 2003b).

The current study presents the ultrastructural characterization of both spermiogenesis and spermatozoa in seven species of Callichthyidae comprised of four Corydoradinae and three Callichthyinae. Comparisons between the data ob-

\footnotetext{
*Faculdade de Medicina de Marília, Marília, São Paulo, Brazil, Caixa Postal 2003, 17519-030 Marília, SP, Brazil, and Departamento de Biologia Celular, Instituto de Biologia, Universidade Estadual de Campinas, Caixa Postal 6109, 13084-971 Campinas, SP, Brazil.

**Departamento de Morfologia, Instituto de Biociências, Universidade Estadual Paulista, Caixa Postal 510, 18618-000 Botucatu, SP, Brazil.morfologia@ibb.unesp.br
} 
tained in this study and those available for other siluriform families were also conducted.

\section{Material and Methods}

The present study was conducted with species of the subfamilies Corydoradinae and Callichthyinae. The fish were identified and kept in the fish collection of Laboratório de Biologia e Genética de Peixes (LBP), Departamento de Morfologia, Instituto de Biociências, UNESP, Botucatu, São Paulo, Brazil. For the subfamily Corydoradinae, we utilized two adult males of Corydoras flaveolus collected from rio Alambari (22 $2^{\circ} 6^{\prime} 08^{\prime \prime}$ S, 48 19'15”W), Botucatu, São Paulo, Brazil (LBP 1314), three adult males of Corydoras aeneus from rio Araquá (2247.135’S, $\left.48^{\circ} 28.892^{\prime} W\right)$, Botucatu, São Paulo, Brazil (LBP 1406), two adult males of Scleromystax lacerdai from rio Ribeira da Terra Firme (15³2'17.9”S, 3900'28.5'W), Canavieiras, Bahia, Brazil (LBP 1966), and three adult males of Aspidoras poecilus from córrego Voadeira, rio Araguaia

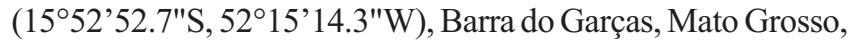
Brazil (LBP 2469). For the subfamily Callichthyinae, we utilized four adult males of Hoplosternum littorale collected from rio Corumbataí $\left(22^{\circ} 15^{\prime} \mathrm{S}, 47^{\circ} 36^{\prime} \mathrm{W}\right)$, Corumbataí, São Paulo, Brazil (LBP 2015); two adult males of Megalechis thoracata from a temporary lagoon, rio Itiquira $\left(17^{\circ} 28^{\prime} 13^{\prime \prime S}\right.$, $55^{\circ} 14^{\prime} 46.7^{\prime \prime W}$ ), Itiquira, Mato Grosso, Brazil (LBP 1930); and two adult males of Callichthys callichthys from Corumbá, Mato Grosso do Sul, Brazil (LBP 1555).

Gonad fragments were fixed in $2 \%$ glutaraldehyde and $4 \%$ paraformaldehyde in 0.1 M Sorensen phosphate buffer, $\mathrm{pH}$ 7.4. The material was post-fixed for $2 \mathrm{~h}$ in the dark in $1 \%$ osmium tetroxide in the same buffer, stained in block with an aqueous solution of $5 \%$ uranyl acetate for $2 \mathrm{~h}$, dehydrated in acetone, embedded in araldite, and sectioned and stained with a saturated solution of uranyl acetate in $50 \%$ ethanol, and with lead citrate (Reynolds, 1963). Electromicrographs were obtained using a Phillips - CM 100 transmission electron microscope.

Sixteen characters present in Callichthyidae were employed in the comparative analyses with others families of Loricarioidea (Table 2). Based on the siluriform spermatozoa described in the literature (Porier \& Nicholson, 1982; Kwon et al., 1998; Lee, 1998; Lee and Kim, 1999; Kim \& Lee, 2000; Quagio-Grassiotto \& Carvalho, 2000; Lee \& Kim, 2001; Quagio-Grassiotto et al., 2001; Santos et al., 2001; Burns et al., 2002; Mansour et al., 2002; Quagio-Grassiotto et al., 2005; Spadella et al., 2006a, b), the midpiece size (character 10) was considered short when its total length was $\leq 1.7 \mu \mathrm{m}$, and long when its total length was $>1.7 \mu \mathrm{m}$. The cytoplasmic channel size (character 12) was considered short when its total length was $\leq 1.5 \mu \mathrm{m}$, and long when its total length was $>1.5 \mu \mathrm{m}$.

\section{Results}

Spermiogenesis in Corydoradinae. In the analyzed species, spermatids are found in the lumen of the testicular tubules together with spermatozoa (Figs. 1c, 1d, 2a). At the beginning of the process, early spermatids remain connected to the Sertoli cell surface (Figs. 2b-2d). During extracystic spermiogenesis, this connection is lost and the more differentiated spermatids move toward the luminal region of the testicular tubules, mixing with spermatozoa. In early spermatids, the centriolar complex lies laterally to the nucleus and the distal

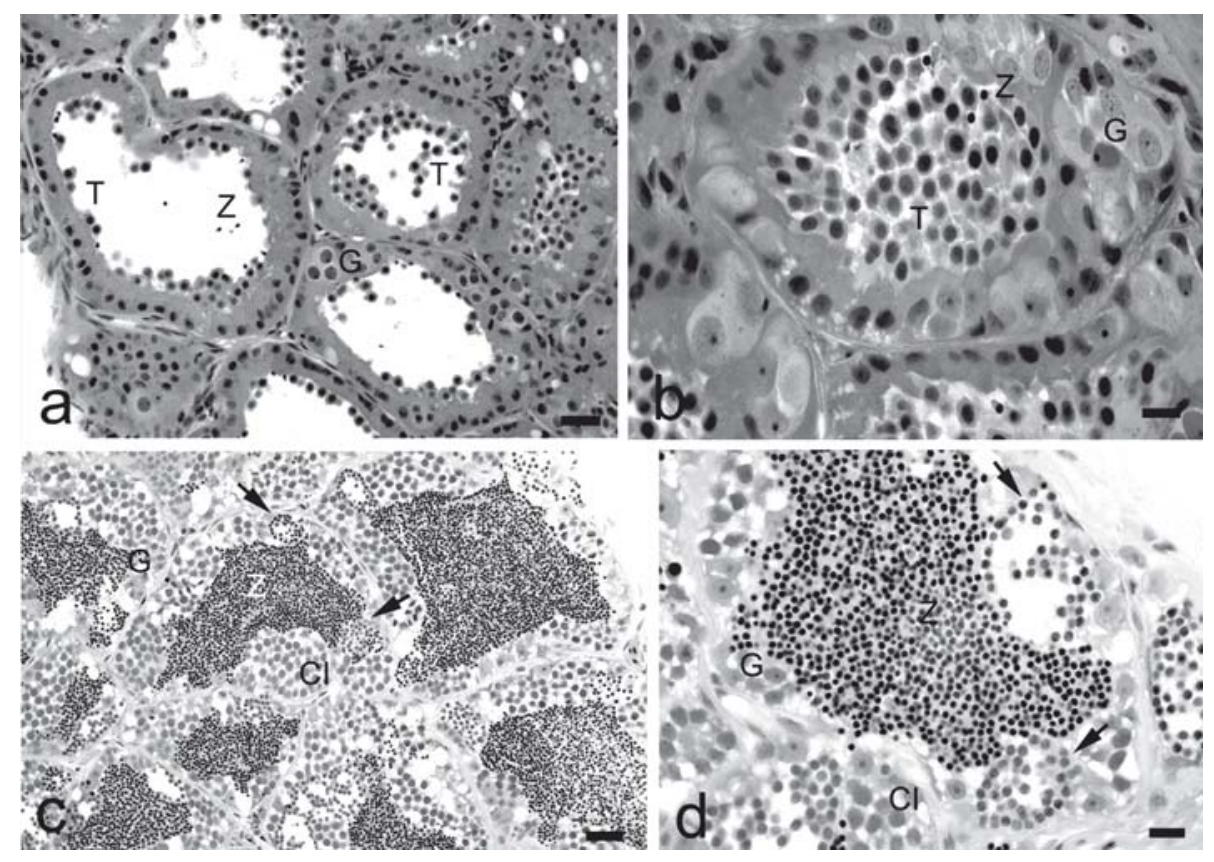

Fig. 1. Photomicrography showing a general view of the semi-cystic spermatogenesis in Corydoras flaveolus, Corydoradinae ( $\mathrm{a}$ and $\mathrm{b}$ ) and of the cystic spermatogenesis in Hoplosternum littorale, Callichthyinae (c and d). Scale bar $\mathbf{a}$ and $\mathbf{c}=20 \mu \mathrm{m}, \mathbf{b}$ and $\mathbf{d}=10 \mu \mathrm{m}$. CI: cysts of primary spermatocytes; G: spermatogonia; T: spermatids in the lumen of germinative compartment; $\mathrm{Z}$ spermatozoa, Arrow: spermatids cysts. 
centriole anchors to the plasma membrane. Development of the flagellum from the distal centriole occurs lateral to the nucleus (Fig. 2e). The centriolar complex does not move toward the nucleus, remaining anchored to the plasma membrane (Figs. $2 \mathrm{f}$ and $2 \mathrm{~g}$ ). The centrioles are coaxial to each other, and between them a linear electron-dense structure, in transverse position to the centriolar axis is observed. Proximal and distal centrioles are fastened to the linear electron dense structure by microfibrils (Figs. 2e and 2e-inset). During spermiogenesis, nuclear rotation does not occur, and the flagellum takes up an eccentric position in relation to the nucleus. A flat depression is formed in the nuclear outline, giving rise to the nuclear fossa. The nuclear fossa is eccentrically positioned, and the centriolar complex is found completely outside of it (Fig. 2e). The chromatin is highly condensed in the form of the thin fibers that confer a homogeneous aspect to the nucleus (Figs. 2g, and 2i). Although the centrioles do not move toward the nucleus, the formation of a cytoplasmic channel occurs (Fig. 2g). The cyto- plasmic mass moves around the initial segment of the tail, and gives rise to the midpiece of the future spermatozoon. The midpiece has elongate mitochondria and vesicles randomly distributed along it (Figs. 2e-2h). Within the cytoplasm of the midpiece the formation of an electron-dense circular structure is also observed (Fig. 2h). The flagellum has a classical (9+2) axoneme, with nine peripheral microtubular doublets of microtubules and a single central pair of microtubules, with neither lateral projection nor fins, and no visible membranous compartment (Fig. 2e-inset).

Spermatozoa of Corydoradinae. The measurements of length and width of nucleus, nuclear fossa, midpiece, and cytoplasmic channel of the spermatozoa of Callichthyinae and Corydoradinae species analyzed are presented in the Table 1.

Corydoradinae spermatozoa have a round or ovoid head, asymmetric midpiece, and one flagellum eccentric to the nucleus (Figs. 3a, 4a, 5a, and 6a). They do not show an acrosomal vesicle.

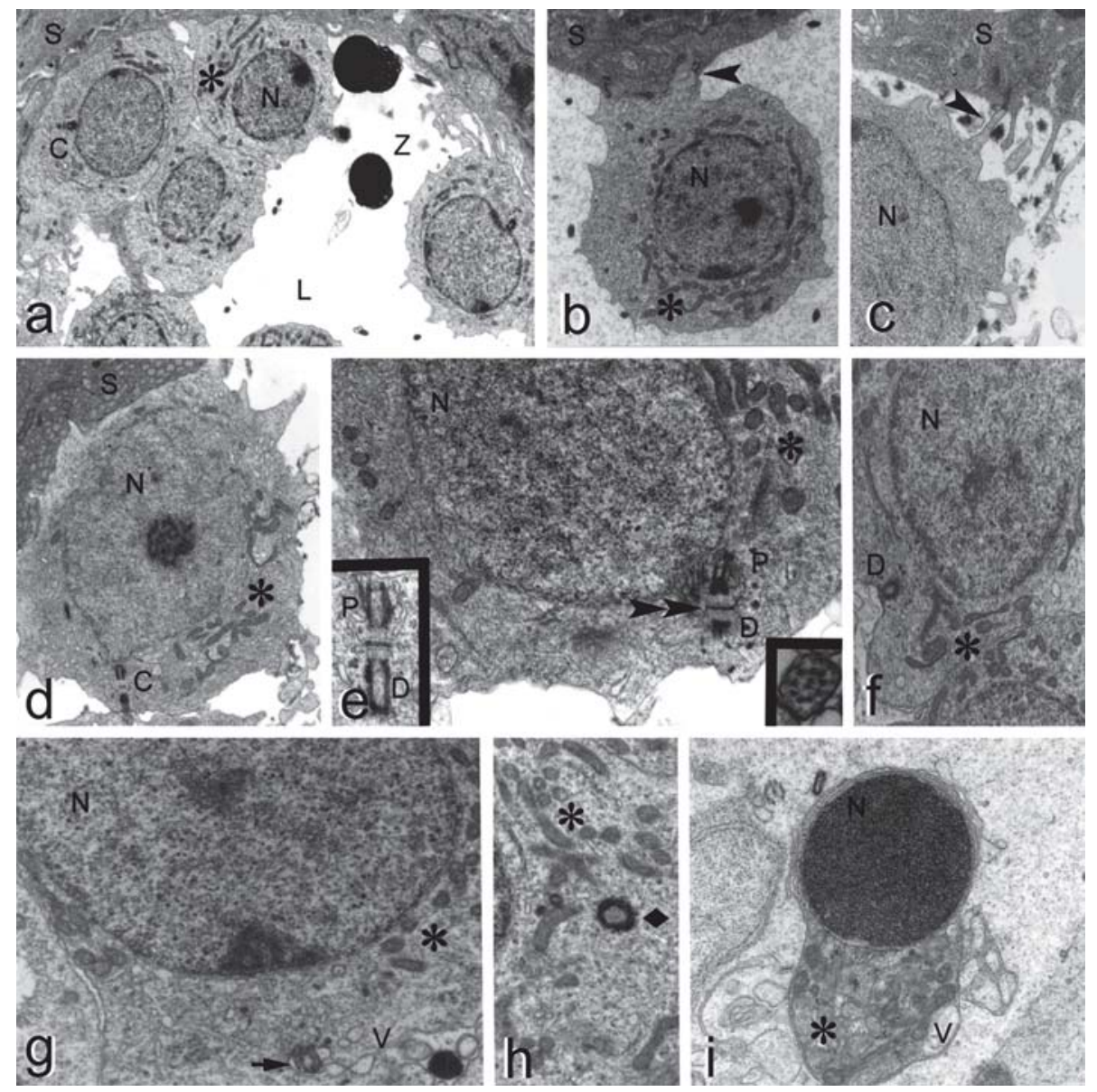

Fig. 2. Spermiogenesis in Corydoradinae. a-d) Corydoras flaveolus; e-h) Corydoras aeneus; i) Scleromystax lacerdai. a) Spermatids together with spermatozoa in the lumen of the testicular tubules. b-d) Early spermatids connected to the Sertoli cells surface. e and e-insets) Arrangement of the centriolar complex showing electron-dense material between centrioles, and flagellum with classical (9+2) axoneme. f to h) Midpiece showing mitochondria, vesicles, and electron-dense circular structure (longitudinal sections). i) Late spermatid. (a) X 3250; (b) X 4875; (c, d) X 5750; (e) X 13250; (e-inset left, i) X 17000; (e-inset right) X 25850; (f, g) X 9750; (h) X 7750. C: centriolar complex; D: distal centriole; L: lumen; N: nucleus; P: proximal centriole; S: Sertoli cell; V: vesicles; Z: spermatozoon; Asterisk: mitochondria, Arrow: cytoplasmic channel; Arrowhead: point connection; Double arrowhead: electron-dense material between the centrioles; Lozenge: electron-dense circular structure. 
In Corydoras flaveolus and C. aeneus, the nuclei have a round shape, while in Scleromystax lacerdai and Aspidoras poecilus, they are ovoid (Figs. 3a-3c, 4a-4c, 5a-5d, and 6a-6d). The chromatin has an homogeneous aspect, interspersed with electronlucent areas. In the cytoplasmic region around the nucleus, no organelles are seen (Figs. 3b-3f, 4c, 4e, 5a-5e, and 6a-6f). The nuclear fossa is eccentric to the nucleus and forms a simple arc (Figs. 3d, 4d, 5d, 5e, and 6d). In this species herein analyzed, there is a large number of elongate mitochondria filling all the regions of the midpiece. The mitochondria are separated from the flagellum by the cytoplasmic channel. Vesicles are observed in the basal extremity of the midpiece distributed around the flagellum (Figs. 3e-3j, 4e-4j, 5d-5g, and 6e-6i). In C. flaveolus, $S$. lacerdai, and A. poecilus, the vesicles are small and can be isolated or interconnected to each other, whereas in C. aeneus they are interconnected to each other. In all species analyzed an electron-dense circular structure in the midpiece cytoplasm is observed, which was formed during the spermiogenesis (Figs. 3f, 3g, 4g, 5a, and 6f-6h). The centrioles are completely outside the nuclear fossa, coaxial to each other, and show an electron-dense structure among them (Figs. 3d, 4d, 5a, 5d, 5e, $6 \mathrm{a}, 6 \mathrm{~d}$, and 6f). The distal centriole is differentiated into the basal body and gives rise to the axoneme, which exhibits the classical $9+2$ microtubular pattern. Although the flagellum of

Table 1. Spermatozoa dimensions in callichthyids, in micrometers. The " $\mathrm{n}$ " shows the number of structures measured.

\begin{tabular}{|c|c|c|c|c|c|c|c|}
\hline \multirow{2}{*}{$\begin{array}{c}\text { Subfamilies } \\
\text { Species }\end{array}$} & \multicolumn{4}{|c|}{ Corydoradinae } & \multicolumn{3}{|c|}{ Callichthyinae } \\
\hline & $\begin{array}{l}\text { Corydoras } \\
\text { flaveolus }\end{array}$ & $\begin{array}{l}\text { Corydoras } \\
\text { aeneus }\end{array}$ & $\begin{array}{l}\text { Scleromystax } \\
\text { lacerdai }\end{array}$ & $\begin{array}{l}\text { Aspidoras } \\
\text { poecilus }\end{array}$ & $\begin{array}{l}\text { Hoplosternum } \\
\text { littorale }\end{array}$ & $\begin{array}{l}\text { Megalechis } \\
\text { thoracata }\end{array}$ & $\begin{array}{l}\text { Callichthys } \\
\text { callichthys }\end{array}$ \\
\hline \multicolumn{8}{|l|}{ Structures } \\
\hline \multicolumn{8}{|l|}{ Nucleus } \\
\hline Length $(\mu \mathrm{m})$ & $\begin{array}{l}1.9 \\
(\mathrm{n}=12)\end{array}$ & $\begin{array}{l}1.6 \\
(n=7)\end{array}$ & $\begin{array}{l}1.5 \\
(\mathrm{n}=7)\end{array}$ & $\begin{array}{l}1.6 \\
(n=6)\end{array}$ & $\begin{array}{l}1.8 \\
(\mathrm{n}=6)\end{array}$ & $\begin{array}{l}1.8 \\
(\mathrm{n}=9)\end{array}$ & $\begin{array}{l}1.7 \\
(n=6)\end{array}$ \\
\hline Width $(\mu \mathrm{m})$ & $\begin{array}{l}2.0 \\
(\mathrm{n}=12)\end{array}$ & $\begin{array}{l}1.7 \\
(n=7)\end{array}$ & $\begin{array}{l}1.6 \\
(\mathrm{n}=7)\end{array}$ & $\begin{array}{l}1.5 \\
(n=6)\end{array}$ & $\begin{array}{l}2.0 \\
(\mathrm{n}=6)\end{array}$ & $\begin{array}{l}1.8 \\
(\mathrm{n}=8)\end{array}$ & $\begin{array}{l}1.6 \\
(n=6)\end{array}$ \\
\hline \multicolumn{8}{|l|}{ Nuclear Fossa } \\
\hline Length $(\mu \mathrm{m})$ & $\begin{array}{l}0.07 \\
(\mathrm{n}=10)\end{array}$ & $\begin{array}{l}0.07 \\
(\mathrm{n}=8)\end{array}$ & $\begin{array}{l}0.07 \\
(\mathrm{n}=8)\end{array}$ & $\begin{array}{l}0.1 \\
(\mathrm{n}=5)\end{array}$ & $\begin{array}{l}0.2 \\
(\mathrm{n}=6)\end{array}$ & $\begin{array}{l}0.2 \\
(n=4)\end{array}$ & $\begin{array}{l}0.2 \\
(\mathrm{n}=5)\end{array}$ \\
\hline Width $(\mu \mathrm{m})$ & $\begin{array}{l}0.3 \\
(\mathrm{n}=10)\end{array}$ & $\begin{array}{l}0.3 \\
(\mathrm{n}=8)\end{array}$ & $\begin{array}{l}0.3 \\
(\mathrm{n}=8)\end{array}$ & $\begin{array}{l}0.3 \\
(\mathrm{n}=5)\end{array}$ & $\begin{array}{l}0.8 \\
(n=6)\end{array}$ & $\begin{array}{l}0.6 \\
(n=4)\end{array}$ & $\begin{array}{l}0.4 \\
(\mathrm{n}=5)\end{array}$ \\
\hline \multicolumn{8}{|l|}{ Midpiece } \\
\hline Length $(\mu \mathrm{m})$ & $\begin{array}{l}1.4 \\
(\mathrm{n}=12)\end{array}$ & $\begin{array}{l}1.3 \\
(\mathrm{n}=6)\end{array}$ & $\begin{array}{l}1.5 \\
(\mathrm{n}=5)\end{array}$ & $\begin{array}{l}1.5 \\
(n=6)\end{array}$ & $\begin{array}{l}1.7 \\
(\mathrm{n}=7)\end{array}$ & $\begin{array}{l}1.6 \\
(n=6)\end{array}$ & $\begin{array}{l}1.5 \\
(n=7)\end{array}$ \\
\hline Width $(\mu \mathrm{m})$ & $\begin{array}{l}2.0 \\
(\mathrm{n}=12)\end{array}$ & $\begin{array}{l}1.9 \\
(\mathrm{n}=6)\end{array}$ & $\begin{array}{l}1.7 \\
(\mathrm{n}=5)\end{array}$ & $\begin{array}{l}1.5 \\
(\mathrm{n}=6)\end{array}$ & $\begin{array}{l}1.9 \\
(\mathrm{n}=7)\end{array}$ & $\begin{array}{l}2.0 \\
(\mathrm{n}=7)\end{array}$ & $\begin{array}{l}1.6 \\
(n=7)\end{array}$ \\
\hline \multicolumn{8}{|c|}{ Cytoplasmic Channel } \\
\hline Length $(\mu \mathrm{m})$ & $\begin{array}{l}0.3 \\
(\mathrm{n}=12)\end{array}$ & $\begin{array}{l}0.3 \\
(\mathrm{n}=7)\end{array}$ & $\begin{array}{l}0.3 \\
(\mathrm{n}=7)\end{array}$ & $\begin{array}{l}0.6 \\
(\mathrm{n}=5)\end{array}$ & $\begin{array}{l}1.5 \\
(\mathrm{n}=5)\end{array}$ & $\begin{array}{l}1.3 \\
(n=4)\end{array}$ & $\begin{array}{l}0.8 \\
(\mathrm{n}=5)\end{array}$ \\
\hline Width $(\mu \mathrm{m})$ & $\begin{array}{l}0.4 \\
(\mathrm{n}=12)\end{array}$ & $\begin{array}{l}0.4 \\
(n=7)\end{array}$ & $\begin{array}{l}0.4 \\
(n=7)\end{array}$ & $\begin{array}{l}0.3 \\
(\mathrm{n}=5)\end{array}$ & $\begin{array}{l}0.4 \\
(\mathrm{n}=5)\end{array}$ & $\begin{array}{l}0.7 \\
(n=4)\end{array}$ & $\begin{array}{l}0.4 \\
(n=5)\end{array}$ \\
\hline
\end{tabular}

Table 2. Distribution of sperm character states in the species analyzed in the present study, as well as other families of Loricarioidea. (+) present; (-) absent. *1- flagella number (a- one; b- two); 2 - arrangement of centriolar complex (a- lateral and parallel; b-lateral and acute angle; c- lateral and obtuse angle; $d$ - anterior and perpendicular; e- anterior and obtuse angle; fco-axial); 3- presence of elongated vesicles; 4- flagellar membrane specializations (a- absent; b- two lateral fins; c- membranous compartment); 5- shape of the nucleus (a- semi-ovoid; b- conic; c- ovoid; d-ovoid with its bigger axis in the horizontal direction; e- spherical); 6- pattern of chromatin condensation (a- heterogeneous; b- homogeneous); 7- nuclear fossa (aabsent; b- medial; c- eccentric); 8- nuclear fossa shape (a- simple arc; b- double arc); 9- centrioles totally inserted in the nuclear fossa; 10- midpiece size (a- short; b- long); 11- cytoplasmic channels (a- absent; b- one; c- two); 12- cytoplasmic channel size (a- short; b-long); 13- mitochondria shape (a- elongated; b- elongated and ramificated); 14- midpiece symmetry (a- symmetric; b- asymmetric); 15- Presence of electron-dense circular structure in the midpiece; 16- flagellum position in relation to the nucleus (a- medial; b- eccentric).

\begin{tabular}{|c|c|c|c|c|c|c|c|c|c|c|c|c|c|c|c|c|c|c|c|c|c|c|c|c|c|c|c|c|c|c|c|c|c|c|c|c|c|c|c|}
\hline Characters* & 1 & & & & 2 & & & & 3 & & 4 & & & & 5 & & & & & & 1 & & 8 & & 3 & 10 & & & 11 & & 12 & & 13 & & & 4 & 15 & 1 & 6 \\
\hline States & $\mathrm{a}$ & $\mathrm{b}$ & $\mathrm{a}$ & $\mathrm{b}$ & o & $\underline{\mathrm{d}}$ & e & $\mathrm{f}$ & - & $\mathrm{a}$ & $\mathrm{b}$ & $\mathrm{c}$ & $\mathrm{a}$ & $\mathrm{b}$ & $\mathrm{c}$ & d & $\mathrm{e}$ & $\mathrm{a}$ & $\mathrm{b}$ & $\mathrm{a}$ & $\mathrm{b}$ & $\mathrm{c}$ & $\mathrm{a}$ & $\mathrm{b}$ & - & $\mathrm{a}$ & $\mathrm{b}$ & $\mathrm{a}$ & $\mathrm{b}$ & $\mathrm{c}$ & $\mathrm{a}$ & $\mathrm{b}$ & $\mathrm{a}$ & $\mathrm{b}$ & $\mathrm{a}$ & $\mathrm{b}$ & - & $\mathrm{a}$ & b \\
\hline ematogenyidae & - & + & + & - & - & - & - & - & + & + & - & - & - & - & - & 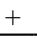 & - & - & + & + & - & - & - & - & - & - & + & - & + & 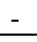 & + & . & - & + & + & - & - & + & - \\
\hline C. flaveolus & + & - & - & - & - & - & - & + & + & - & - & + & - & - & - & - & + & - & + & - & - & + & + & - & - & + & - & - & + & - & + & - & + & - & - & + & + & . & + \\
\hline C. aeneus & + & - & - & - & - & - & - & + & + & - & - & + & - & - & - & - & + & - & + & - & - & + & + & - & - & + & - & - & + & - & + & - & + & - & - & + & + & - & + \\
\hline lacerdai & + & - & - & - & - & - & - & + & + & - & - & + & - & - & + & - & - & - & + & - & - & + & + & - & - & + & - & - & + & - & + & - & + & - & - & + & . & - & + \\
\hline 1. poecilus & + & - & - & - & - & - & - & + & + & - & - & + & - & - & + & - & - & - & + & - & - & + & + & - & - & + & - & - & + & - & + & - & + & - & - & + & + & 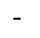 & + \\
\hline H. littorale & + & - & - & + & - & - & - & - & + & + & - & - & - & - & + & - & - & - & + & - & - & + & + & - & + & + & - & - & + & - & + & - & + & - & - & + & . & - & + \\
\hline M. thoracata & + & - & - & - & + & - & - & - & + & + & - & - & - & - & - & - & + & - & + & - & + & - & + & - & + & + & - & - & + & - & + & - & + & - & + & - & - & + & - \\
\hline C. callichthys & + & - & - & - & + & - & - & - & + & - & - & + & - & - & + & - & - & - & + & - & - & + & + & - & - & + & - & - & + & - & + & - & + & - & - & + & - & - & + \\
\hline coloplacidae & + & - & - & - & - & + & - & - & + & - & + & - & 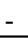 & + & - & - & - & - & + & - & + & - & + & - & + & - & + & - & + & - & - & + & + & - & + & - & - & + & - \\
\hline oricariidae & + & - & - & - & - & + & - & - & - & + & - & - & - & - & - & - & + & + & - & - & + & - & + & - & + & + & - & - & + & - & + & - & + & - & + & - & - & + & - \\
\hline
\end{tabular}


the spermatids does not contain vesicles or tubules, the flagellum of the spermatozoon displays some regions with a membranous compartment, whereas in others this compartment is not observed (Figs. 3k-3n, 4k-4n, 5a, 5h, and 6j-6l).

Spermiogenesis in Callichthyinae. In the analyzed species of Callichthyinae, spermiogenesis occurs within spermatocysts in the germinal epithelium. In these cysts, groups of spermatids at the same development stage are surrounded by cytoplasmic processes of the Sertoli cells (Figs. 1a, 1b, and 7a). In the cysts, the early spermatids are interconnected by cytoplasmic bridges that result from incomplete cytokinesis during cellular divisions. In the early spermatids, the cytoplasm is symmetrically distributed around the nucleus, which contains

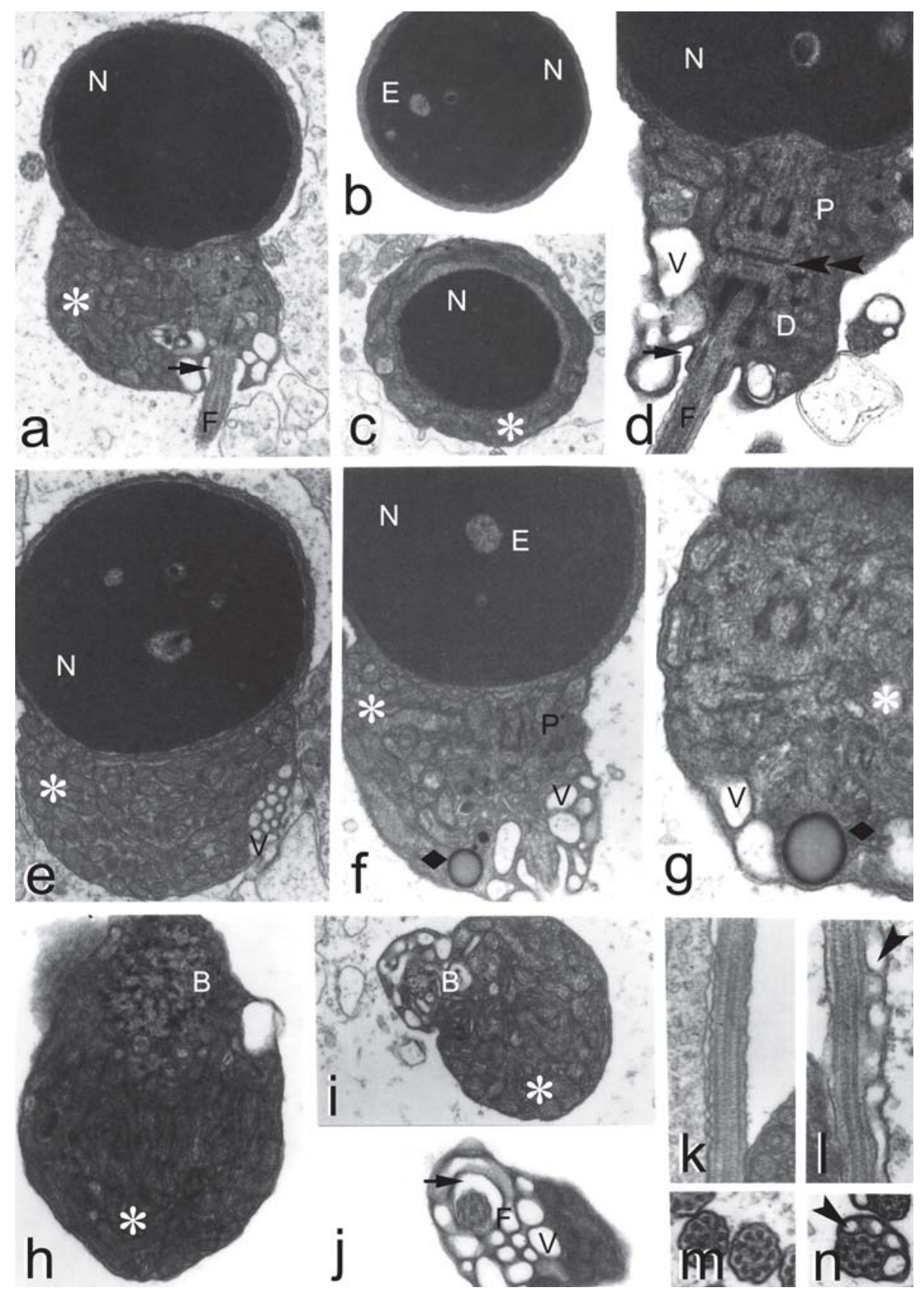

Fig. 3. Spermatozoa of Corydoras flaveolus. a) Spermatozoon longitudinal section. b and c) Nucleus in transverse sections. d) Detail of centriolar arrangement. e to j) Midpiece longitudinal and transverse sections showing mitochondria, vesicles, cytoplasmic channel, and electron-dense circular structure. $\mathbf{k}$ and $\mathbf{l}$ ) Flagellum longitudinal sections. $\mathbf{m}$ and $\mathbf{n}$ ) Flagellum cross sections. (a) X 17000; (b, c) X 15750; (d) X 28350; (e, f, h) X 23000; (g, m) X 42000; (i) X 18900; (j) X 25200; (k) X 25300; (l, n) X 31500. B: basal body; D: distal centriole; E: electron-dense structure; F: flagellum; N: nucleus; P: proximal centriole; V: vesicles; Asterisk: mitochondria, Arrow: cytoplasmic channel; Arrowhead: lateral membranous compartment; Double arrowhead: electron-dense material between the centrioles; Lozenge: electron-dense circular structure. 
diffuse chromatin and has a circular outline (Figs. 7b, 7d, 7i, and $7 \mathrm{n}$ ). The centriolar complex, with the proximal centriole at an obtuse angle to the distal in Megalechis thoracata and Callichthys callichthys, and lateral and at an acute angle in Hoplosternum littorale, lies laterally to the nucleus and is anchored to the plasma membrane. Flagellar development from the distal centriole takes place laterally to the nucleus (Figs. 7c, $7 \mathrm{~d}, 7 \mathrm{j}, 7 \mathrm{l}$, and $7 \mathrm{o}$ ). The centriolar complex moves toward the nucleus bringing with it the plasma membrane and the initial segment of the flagellum causing an invagination (Figs. 7e, 7j, and $7 \mathrm{n}$ ). With this movement, the cytoplasmic canal, a space between the plasma membranes of the flagellar region and the

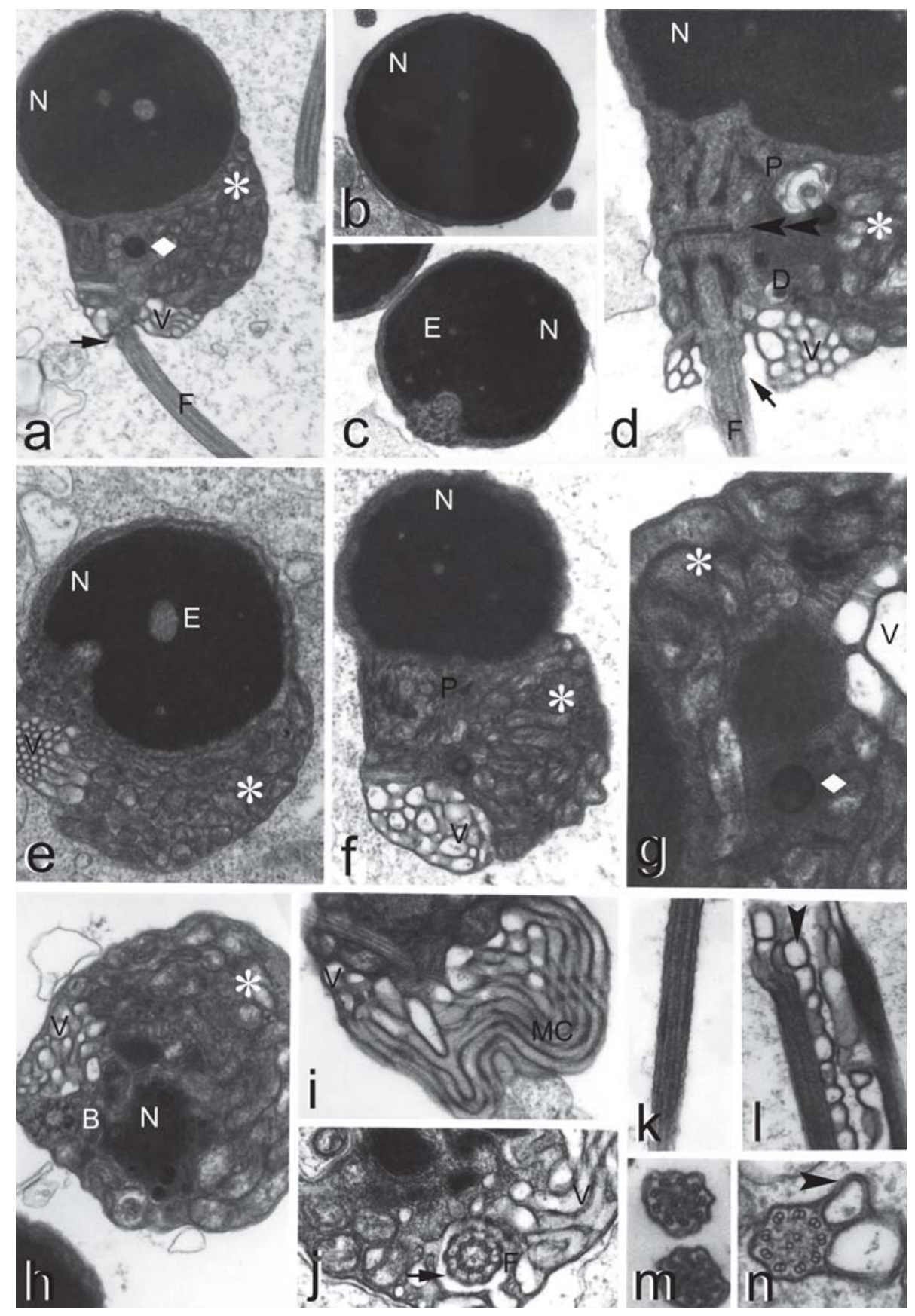

Fig. 4. Spermatozoa of Corydoras aeneus. a) Longitudinal section. $\mathbf{b}$ and $\mathbf{c})$ Nucleus in cross sections. d) Detail of centriolar arrangement. e to j) Midpiece longitudinal and transverse sections showing mitochondria, vesicles, membranous compartment, and electron-dense circular structure. $\mathbf{k}$ and $\mathbf{l})$ Flagellum in longitudinal sections. $\mathbf{m}$ and $\mathbf{n}$ ) Flagellum in cross sections. (a, d) X 17000; (b) X 13800; (c) X 15750; (e, h, k, l) X 23000; (f) X 20400; (g) 44100; (i, j) X 31500; (m) X 47250; (n) X 57500. B: basal body; D: distal centriole; E: electron-dense structure; F: flagellum; N: nucleus; P: proximal centriole; V: vesicles; Asterisk: mitochondria, Arrow: cytoplasmic channel; Arrowhead: lateral membranous compartment; Double arrowhead: electron-dense material between the centrioles; Lozenge: electron-dense circular structure. 
main part of the spermatid, is formed. Nuclear rotation occurs in different degrees among the Callichthyinae analyzed, being partial in H. littorale and C. callichthys, and complete in $M$. thoracata. This results in the eccentric position of the flagellum in relation to the nucleus in $H$. littorale and C. callichthys, and medial position in M. thoracata (Figs. 7d, 7e, 7i, 7j, 7n, and 7o). During nuclear rotation, a depression is formed in the nuclear outline that gives rise to the nuclear fossa. At the end of this process, the centrioles are found inserted in the nuclear fossa in H. littorale and M. thoracata, whereas in C. callichthys only the proximal centriole is found inserted in the nuclear fossa. The nuclear fossa is eccentrically positioned in $H$. littorale and C. callichthys, and medial in M. thoracata (Figs. $7 \mathrm{~b}-7 \mathrm{~d}, 7 \mathrm{i}, 7 \mathrm{j}$, and 7o). During nuclear rotation, chromatin condensation commences. The chromatin is progressively and homogeneously condensed, presenting areas of diffuse chroma- tin among areas of condensing chromatin (Figs. 7e, 7j, and 7o). The cytoplasmic mass moves around the initial segment of the tail, and gives rise to the midpiece of the future spermatozoon. The midpiece has rounded to elongate mitochondria and vesicles randomly distributed (Figs. 7e, 7f, 7j, 7k, 7o, and 7p). The flagellum exhibits the classical $(9+2)$ axoneme surrounded by the flagellar membrane, which does not form lateral projections. Membranous compartments are not seen in H. littorale and $M$. thoracata, whereas in C. callichthys the formation of a membranous compartment from the flagellar membrane occurs in some segments of the tail (Figs. 7g, 7h, 7m, and 7q).

Spermatozoa of Callichthyinae. Spermatozoa of Callichthyinae are found in the lumen of the testicular tubules. Hoplosternum littorale and Callichthys callichthys spermatozoa exhibit an ovoid head with an ovoid nucleus, an asymmetric midpiece,

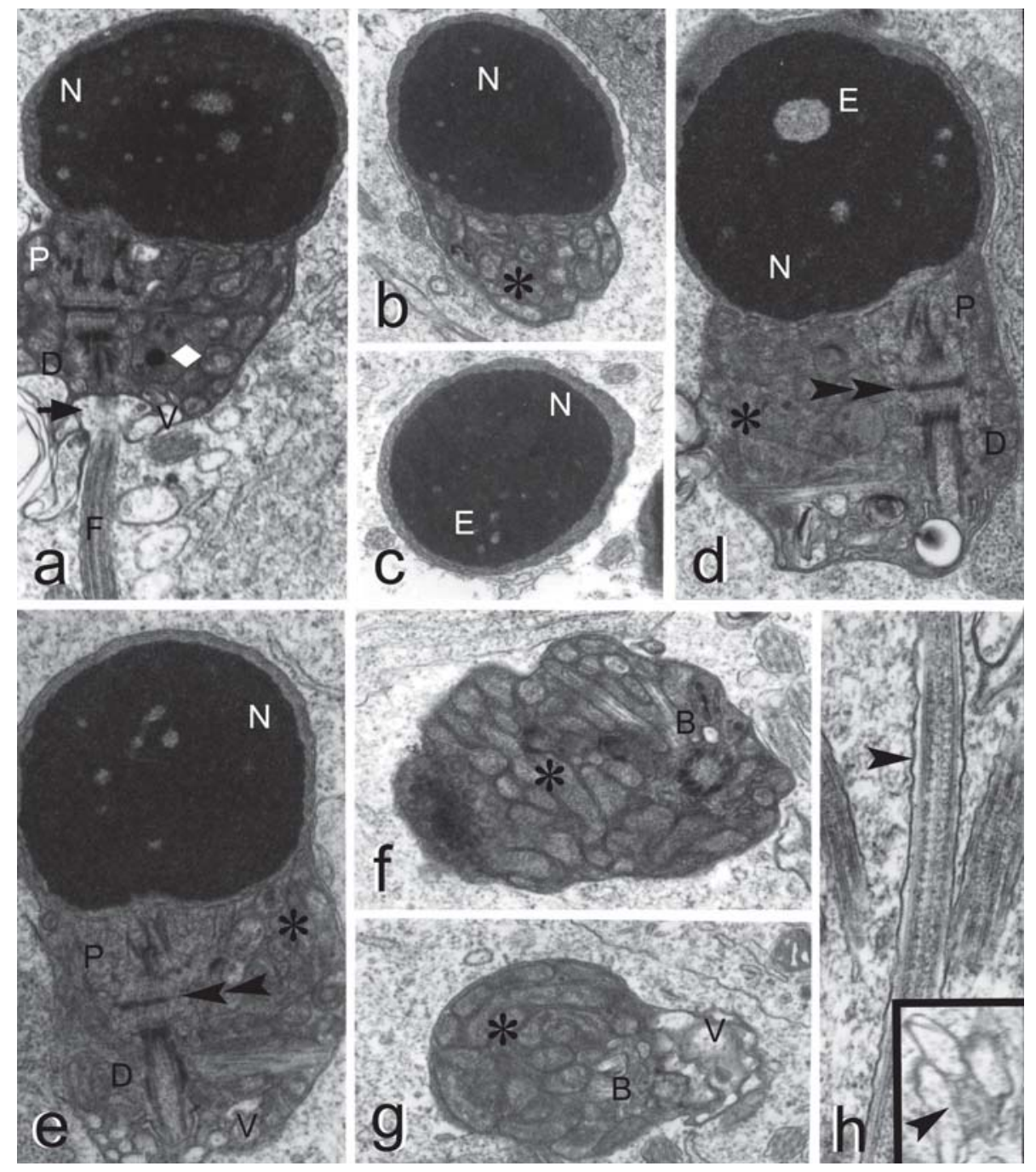

Fig. 5. Spermatozoa of Scleromystax lacerdai. a) Spermatozoon longitudinal section. b and c) Nucleus in longitudinal and cross sections. d) Detail of centriolar arrangement. e to g) Midpiece in longitudinal and transverse sections showing mitochondria and vesicles. h) Flagellum in longitudinal section. h-inset) Flagellum in cross section. (a, d, e) X23000; (b, c) X 17000; (f) X25200; (g) X 20400; (h) X 42000; (h-inset) X 32200. B: basal body; D: distal centriole; E: electron-dense structure; F: flagellum; N: nucleus; P: proximal centriole; V: vesicles; Asterisk: mitochondria, Arrow: cytoplasmic channel; Arrowhead: lateral membranous compartment; Double arrowhead: electron-dense material between the centrioles; Lozenge: electron-dense circular structure. 
and one flagellum eccentric to the nucleus (Figs. 8a, 8b, 8d, 8e, $10 \mathrm{a}$, and 10e). In the spermatozoa of Megalechis thoracata there is a spherical head that contains a spherical nucleus, a symmetric midpiece, and one flagellum medial to the nucleus (Figs. 9a, 9d, and 9e). In this species, the head does not show an acrosomal vesicle. The chromatin has an homogeneous as- pect, interspersed with electron-lucent areas (Figs. 8a, 8d, 9a$9 \mathrm{~d}, 10 \mathrm{~b}, 10 \mathrm{c}$, and 10e). No organelles are seen in the cytoplasmic region around the nucleus. The nuclear fossa in $H$. littorale and $C$. callichthys is eccentric in relation to the nucleus, and forms a simple arc (Figs. 8d, 8e, 10a, 10d, and 10e). In $M$. thoracata, the nuclear fossa is medial to the nucleus and is
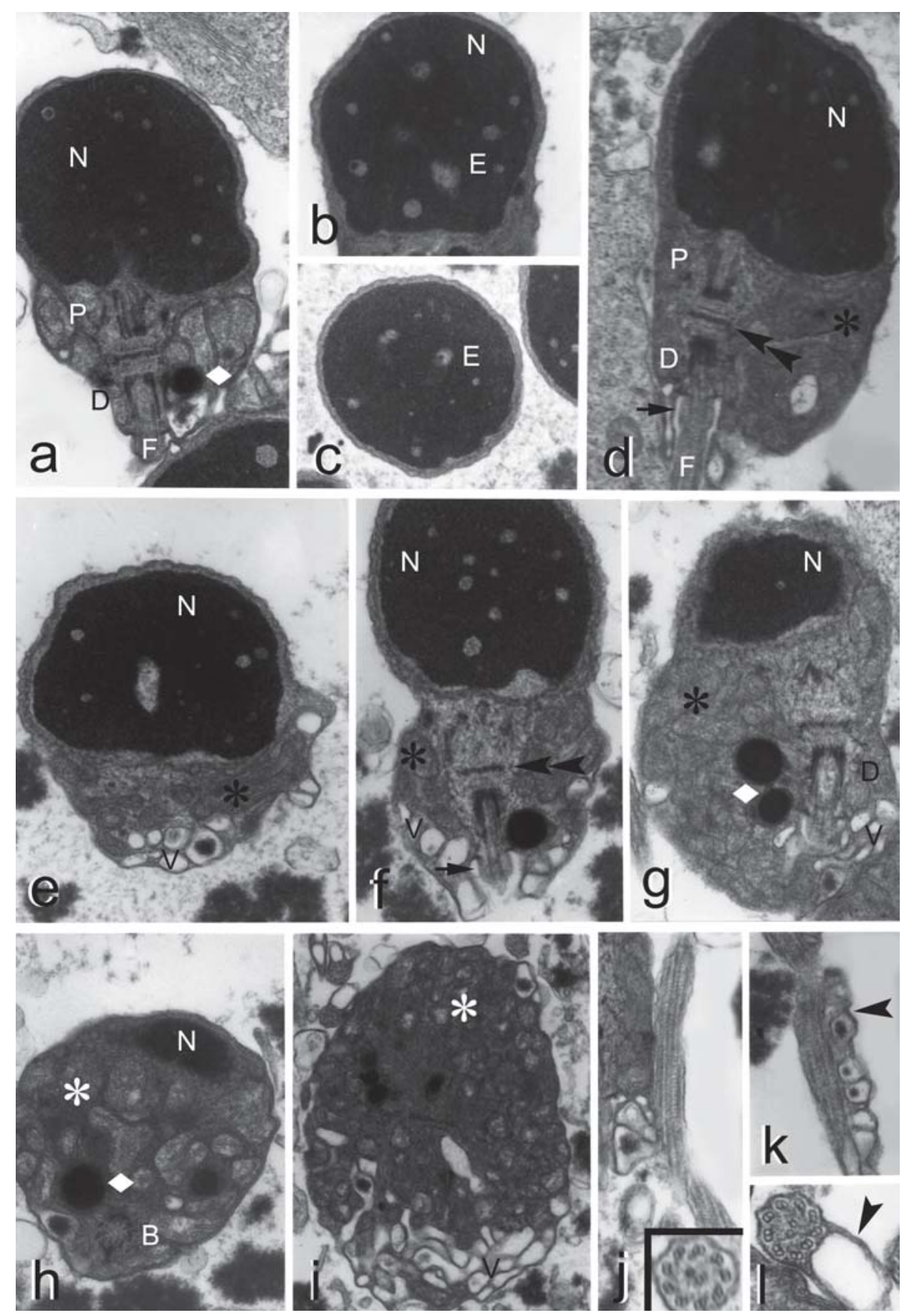

Fig. 6. Spermatozoa of Aspidoras poecilus. a) Spermatozoon longitudinal section. b and c) Nucleus in longitudinal and cross sections. d) Centriolar arrangement. e to i) Midpiece in longitudinal and transverse sections showing mitochondria, vesicles, cytoplasmic channel, and electron-dense circular structures. j and k) Flagellum in longitudinal sections. j-inset and $\mathbf{~})$ Flagellum in cross sections. (a, b, f, j, k) X 23000; (c, d) X 17000; (e) X 22050; (g, h) X 25200; (i) X 18400; (j-inset, l) X 57500. B: basal body; D: distal centriole; E: electron-dense structure; F: flagellum; N: nucleus; P: proximal centriole; V: vesicles; Asterisk: mitochondria, Arrow: cytoplasmic channel; Arrowhead: lateral membranous compartment; Double arrowhead: electron-dense material between the centrioles; Lozenge: electron-dense circular structure. 
also arc shaped (Figs. 9a, and 9d). Many large vesicles or cysternae, either interconnected to each other or not, are observed in the midpiece of $H$. littorale and $M$. thoracata, concentrated in the basal region around the flagellum (Figs. 8e, 8f$8 \mathrm{i}, 9 \mathrm{a}, 9 \mathrm{~d}$, and 9e-9g). In the midpiece of $C$. callichthys, the few elongated vesicles are mainly found around the flagellum (Figs. 10d, 10f, and 10g). In Callichthyinae, several mitochondria concentrated at the apical and medial midpiece regions (Figs. 8c$8 \mathrm{e}, 8 \mathrm{~g}, 8 \mathrm{~h}, 9 \mathrm{e}-9 \mathrm{~h}, 10 \mathrm{a}$, and 10d-10g). The mitochondria are separated from the flagella by the cytoplasmic channel (Figs. 8h, 8i,
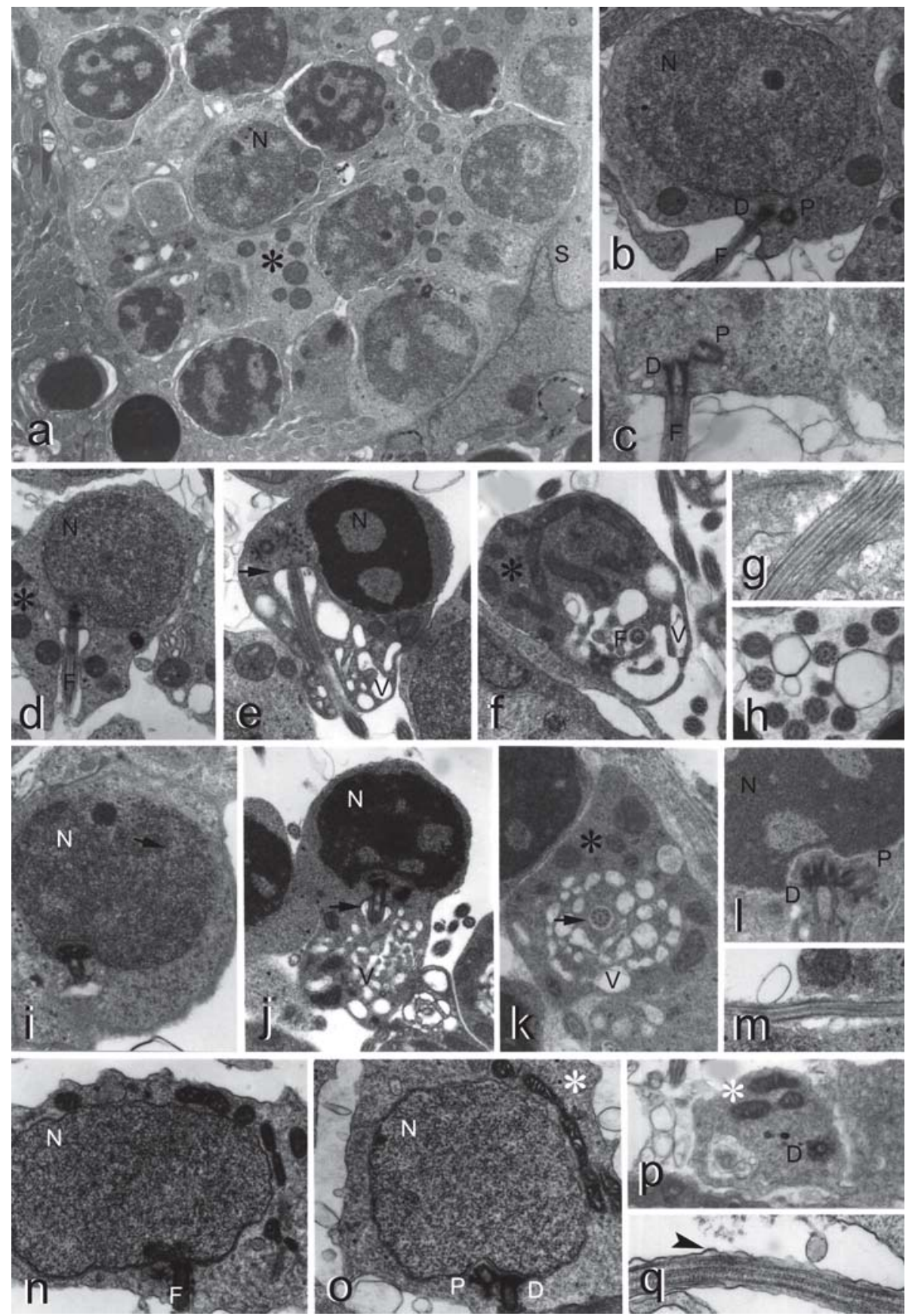

Fig. 7. Spermiogenesis in Callichthyinae. a to h) Hoplosternum littorale. a) Spermatid cyst. b and d) Early spermatids (longitudinal sections). c) Centriolar arrangement. e) Late spermatid. f) Midpiece showing mitochondria and vesicles (cross section). $\mathbf{g}$ and $\mathbf{h}$ ) Flagellum (longitudinal and cross sections). i to $\mathbf{m}$ ) Megalechis thoracata. i) Early spermatid in longitudinal section. $\mathbf{j}$ ) Late spermatid. k) Midpiece showing mitochondria, cytoplasmic channel, and vesicles (cross section). l) Centriolar arrangement. m) Flagellum in longitudinal section. $\mathbf{n}$ to q) Callichtys callichthys. $\mathbf{n}$ and o) Early spermatids in longitudinal sections. p) Midpiece showing mitochondria. q) Flagellum in longitudinal section. (a) X 7750; (b, f, i, n, p) X 13250; (c, g, k, m) X 17000; (d) X 10200; (e, j) X 11900; (h) 20400; (I) X 23000; (o) X 13600; (q) X31500. D: distal centriole; F: flagellum; N: nucleus; P: proximal centriole; S: Setoli cell; V: vesicles; Asterisk: mitochondria, Arrow: cytoplasmic channel; Arrowhead: lateral membranous compartment. 
9i, 9j, and $10 \mathrm{~g}$ ). In M. thoracata and C. callichthys, the proximal centrioles form an obtuse angle in relation to the distal, whereas in $H$. littorale the arrangement of the centriolar complex is lateral and forms an acute angle. A large portion of the centriolar complex lies within the nuclear fossa in $H$. littorale and $M$. thoracata, whereas in C. callichthys only a portion of the proximal centrioles is found within the nuclear fossa (Figs. 8d, 8e, 9a, 9d, 10d, and 10e). The distal centriole becomes the basal body, and gives rise to an axoneme that exhibits the classical 9+2 microtubular pattern. No flagellar lateral projections or membranous compartment are present in $H$. littorale and $M$. thoracata, while in C. callichthys there is a membranous com-
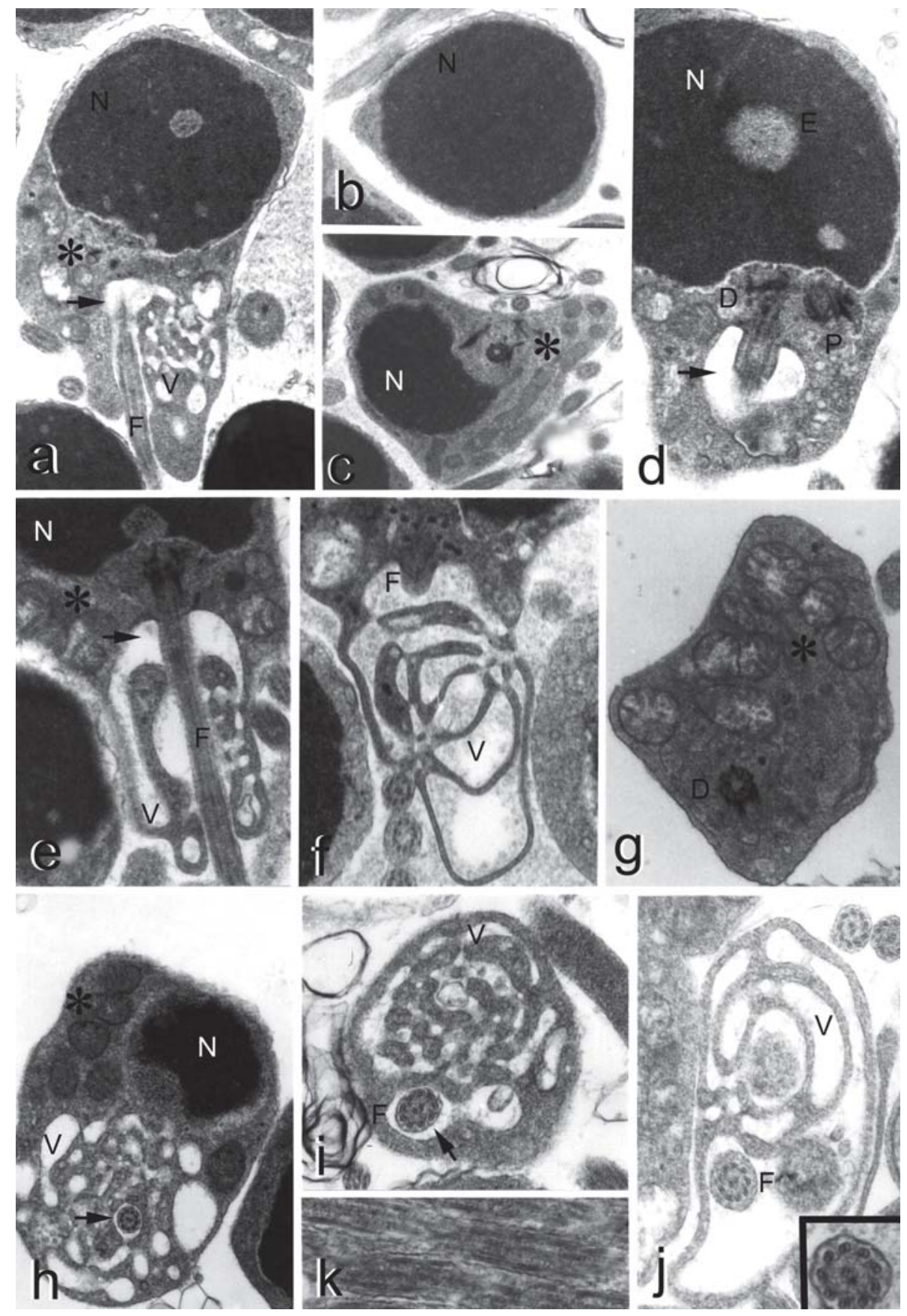

Fig. 8. Spermatozoa of Hoplosternum littorale. a) Spermatozoon in longitudinal section. b and c) Nucleus in cross sections. d) Detail of centriolar arrangement. $\mathbf{e}$ to j) Midpiece in longitudinal and transverse sections showing mitochondria, elongated vesicles, and cytoplasmic channel. k) Flagellum in longitudinal section. $\mathbf{j}$-inset) Flagellum in cross section showing classical (9+2) axoneme. (a, b, h) X 17000; (c) X 13800; (d to g) X 23000; (i) X 33600; (j, k) X 31500; (j-inset) X 57500. D: distal centriole; E: electron-dense structure; F: flagellum; N: nucleus; P: proximal centriole; V: vesicles; Asterisk: mitochondria, Arrow: cytoplasmic channel. 
partment in some regions of the flagellum (Figs. 8j, 8k, 9k, 91, 10h, and 10i).

\section{Discussion}

Spermatogenesis and Spermiogenesis. The occurrence of spermatids in the lumen of the testicular tubules together with spermatozoa in the species of Corydoradinae suggests that spermatogenesis in this subfamily is of the semicystic type. This type of spermatogenesis was described in Cetopsidae and Aspredinidae (Spadella et al., 2006a), and also found in Nematogenyidae (our unpublished data). Although uncommon, semicystic spermatogenesis has been described in others families of Teleostei such as Opheliidae (Mattei et al., 1993), Scorpaenidae (Muñoz et al., 2002), and
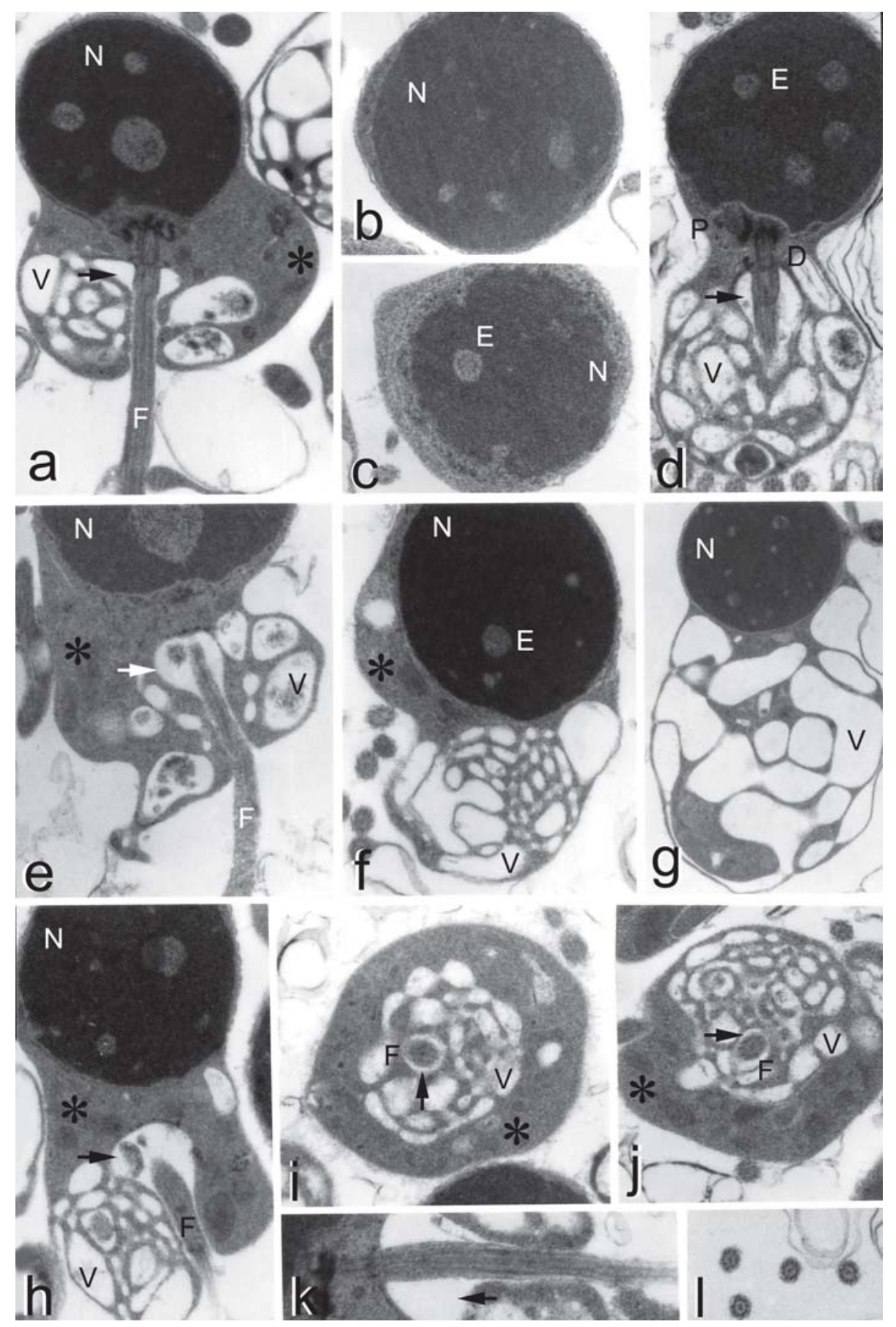

Fig. 9. Spermatozoa of Megalechis thoracata. a) Longitudinal section. b and c) Nucleus in cross sections. d) Detail of centriolar arrangement. e to j) Midpiece in longitudinal and transverse sections showing mitochondria, elongated vesicles, and cytoplasmic channel. $\mathbf{k}$ and l) Flagellum in longitudinal and cross sections. (a to e, h) X 17000; (f, i, j) X 18400; (g) X 11925; (k) X 23000; (I) X 13950. D: distal centriole; E: electron-dense structure; F: flagellum; N: nucleus; P: proximal centriole; V: vesicles; Asterisk: mitochondria, Arrow: cytoplasmic channel. 


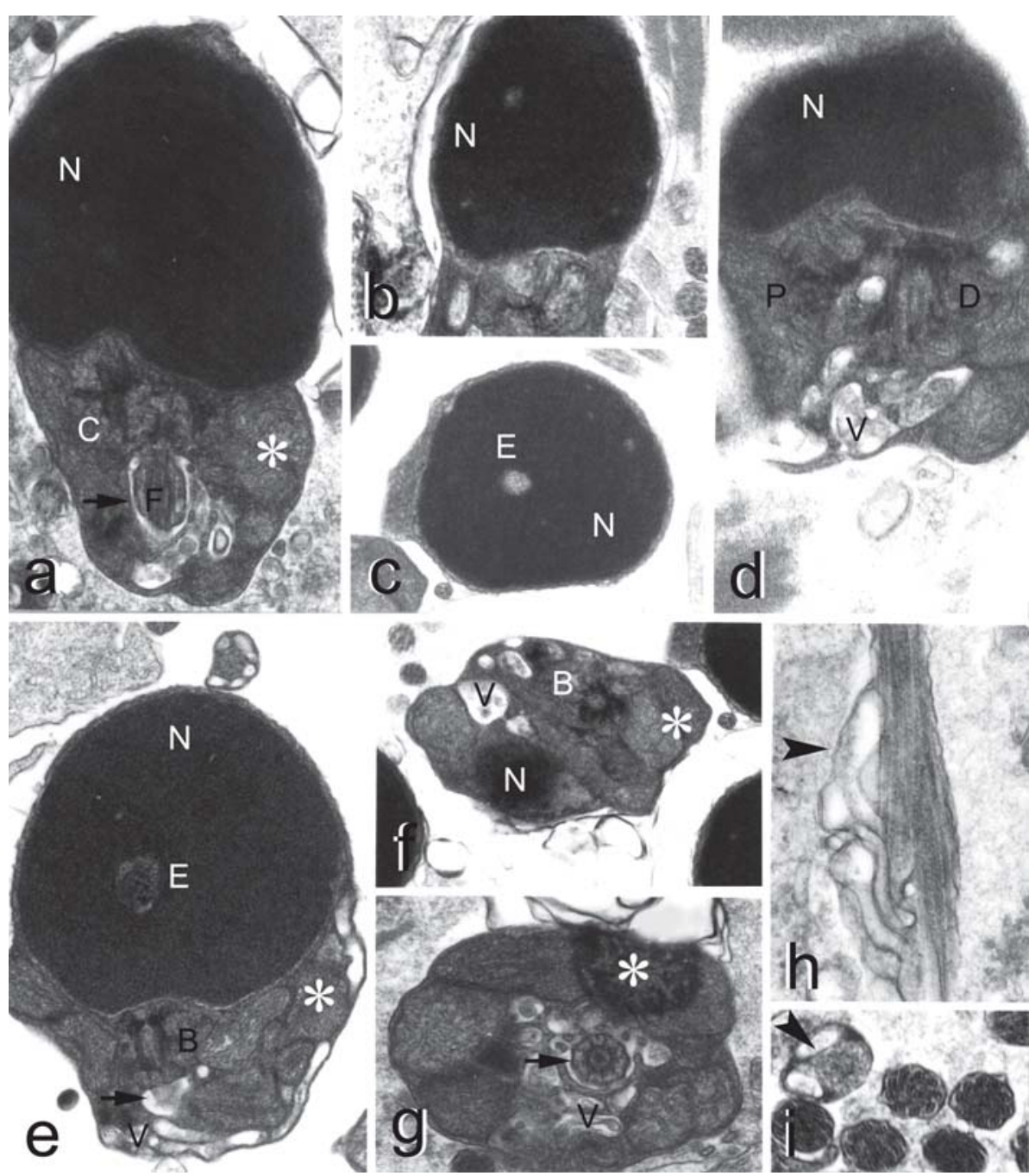

Fig. 10. Spermatozoa of Callichthys callichthys. a) Spermatozoon in longitudinal section. b and c) Nucleus in longitudinal and cross sections. d) Centriolar arrangement. e to g) Midpiece in longitudinal and transverse sections showing mitochondria, vesicles, and cytoplasmic channel. $\mathbf{h}$ and i) Flagellum in longitudinal and cross sections. (a, g, h) X 31500; (b, e) X 23000; (c, f) X 17000; (d, i) X 42000. D: distal centriole; E: electron-dense structure; F: flagellum; N: nucleus; P: proximal centriole; V: vesicles; Asterisk: mitochondria, Arrow: cytoplasmic channel; Arrowhead: lateral membranous compartment.

\section{Bleniidae (Lahnsteiner \& Patzer, 1990).}

In the Callichthyinae, sperm production occurs completely within spermatocysts in the germinal epithelium, characterizing this spermatogenesis as the cystic type. This type of spermatogenesis is present in most Teleostei (Mattei et al., 1993; Quagio-Grassiotto et al., 2001; Quagio-Grassiotto et al., 2003; Quagio-Grassiotto et al., 2005).

In the spermatozoa, the flagellar axis may be either perpendicular or parallel to the nucleus, depending on whether nuclear rotation during spermiogenesis occurs (type I spermiogenesis) or not (type II spermiogenesis) (Mattei, 1970). In Pimelodidae and Heptapteridae, the flagellum is medial, the nucleus does not rotate, and both the nuclear fossa and the cytoplasmic channel are absent during spermiogenesis, characterizing a third type of spermiogenesis (Quagio-Grassiotto et al., 2005; Quagio-Grassiotto \& Oliveira, 2007). The process of spermiogenesis observed in Corydoradinae is characterized by an eccentric development of the flagellum, the absence of nuclear rotation, formation of an eccentric nuclear fossa, formation of a cytoplasmic channel formation, and the absence of centriolar migration. This set of characteristics is different from those previously described. This unusual process of spermiogenesis found in Corydoradinae, except for the eccentric development of the flagellum and nuclear fossa, was also observed in Cetopsidae and Aspredinidae (Spadella et al., 2006a).

It is possible that in the subfamily Corydoradinae the cytoplasmic channel results from the interconnection of the vesicles around the flagellum rather than the movement of the centrioles toward the nucleus. It is probable that a similar process occurs in Cetopsidae, Aspredinidae, and Nematogenyidae (Spadella et al., 2006a).

Spermiogenesis in Callichthyinae is characterized by an initial lateral development of the flagellum, the presence of nuclear rotation to varying degrees, formation of an eccentric or medial nuclear fossa, formation of a cytoplasmic channel and the presence of centriolar migration. This set of charac- 
teristics is more similar to type I spermiogenesis, which is also observed in Diplomystidae, the most basal siluriform family (Quagio-Grassiotto et al., 2001), in Scoloplacidae (Spadella et al., 2006b), and in Pseudopimelodidae (QuagioGrassiotto et al., 2005). However, in Diplomystidae the cytoplasmic channel does not remain in the spermatozoa (QuagioGrassiotto et al., 2001) as observed in Callichthyinae, Scoloplacidae, and Pseudopimelodidae. Furthermore, nuclear rotation in Diplomystidae, Scoloplacidae, and Pseudopimelodidae is complete, resulting in a flagellum perpendicular to the nucleus in the spermatozoon, whereas in Hoplosternum littorale and Callichthys callichthys it is partial, and in Megalechis thoracata it is complete, resulting in the eccentric position of the flagellum in H. littorale and $C$. callichthys and medial in M. thoracata. Mattei (1970) felt that the occurrence of intermediate processes of spermiogenesis is responsible for the formation of these intermediate spermatozoa, whose flagella are eccentric to the nucleus.

The characteristics of the process of spermatogenesis and spermiogenesis in the Corydoradinae and Callichthyinae revealed clear unique characters for each of these subfamilies, corroborating the hypotheses that they constitute monophyletic groups (Reis, 1998; Shimabukuro-Dias et al., 2004).

Spermatozoa. The comparative analyses of callichthyid sperm ultrastructure presented in Table 2 showed that species herein analyzed share the same character states in eight out of the sixteen characters observed (characters $1,3,6,8$, and 10 to 13). These characters are also share with other siluriform families constituting plesiomorphic characters for the family Callichthyidae.

Callichthyids sperm ultrastructure showed that character 2 , arrangement of complex centriolar, is variable among the species analyzed, being co-axial in all Corydoradinae, lateral in acute angle in Hoplosternum littorale, and lateral in obtuse angle in Megalechis thoracata and Callichthys callichthys. The state "character co-axial" is only found in Corydoradinae, which represents a synapomorphic character of this subfamily. The other character state, arrangement of complex centriolar, found in Callichthyinae, is also observed in Trichomycteridae (our unpublished data).

The presence of the membranous compartment in the flagellum (character 4) is found in the majority of the species of Callichthyidae (species of Corydoradinae and Callichthys callichthys). A similar characteristic was also observed in Trichomycteridae, other members of Loricarioidea (our unpublished data), and in Characiformes of the family Curimatidae (Quagio-Grassiotto et al., 2003).

The only character not shared by all Corydoradinae is the shape of the nucleus (character 5), which is spherical in Corydoras flaveolus and C. aeneus, whereas in Scleromystax lacerdai and Aspidoras poecilus, the nucleus is ovoid (Table 2). In a phylogenetic study of the subfamily Corydoradinae conducted by Britto (2003b) with 83 morphological characters the author corroborates the monophyly of the subfamily and showed that Aspidoras is more related to Scleromystax. The data obtained in the present study corroborate this hypothesis.

Some characteristics are shared by all Corydoradinae and some species of Callichthyinae (Table 2). For example, the presence of a membranous compartment in the flagellum and centrioles outside of the nuclear fossa occurs in Corydoradinae and in Callichthys callichthys (characters 4 and 9 , respectively), the occurrence of eccentric nuclear fossa (Character 7), presence of asymmetric midpiece (character 14), presence of eccentric flagellum position in relation to the nucleus (character 15), and medial position of flagellum in relation to the nucleus (character 16) are found in Corydoradinae and in Hoplosternum littorale and $C$. callichthys. There was no characteristic exclusively found in the spermatozoa of Callichthyinae. Most of the characteristics of spermatozoon of $C$. callichthys (Callichthyinae) were similar with those found among the species of Corydoradinae.

Character 15, presence of electron-dense circular structure in the midpiece, is also shared by all Corydoradinae species, representing an other unique character of this subfamily, not observed in any other siluriform up to the present (Poirier \& Nicholson, 1982; Emel'yanova \& Makeyeva, 1991a, b; Kwon et al., 1998; Lee, 1998; Lee \& Kim, 1999; Kim \& Lee, 2000; Quagio-Grassiotto \& Carvalho, 2000; Lee \& Kim, 2001; Quagio-Grassiotto et al., 2001; Santos et al., 2001; Burns et al., 2002; Mansour et al., 2002; Mansour \& Lahnsteiner, 2003; Quagio-Grassiotto et al., 2005).

Considering the phylogeny of the superfamily Loricarioidea, the family Callichthyidae is a sister group of the clade formed by Scoloplacidae, Astroblepidae, and Loricariidae (de Pinna, 1998; Britto, 2003a). Table 2 shows that one or more species of Callichthyidae share eight characteristics with Nematogenyidae (another family of Loricarioidea), ten characters with Scoloplacidae, and twelve with Loricariidae. As observed above, Callichthyidae spermatozoa share more characters with Scoloplacidae and Loricariidae than with Nematogenyidae, corroborating the previous hypotheses of relationships of the superfamily Loricarioidea proposed by de Pinna (1998) and Britto (2003a).

Characteristics shared by Callichthyids and others families of Loricarioidea (Table 2) are also found in other siluriform families: Diplomystidae (Quagio-Grassiotto et al., 2001), Amblycipitidae (Lee \& Kim, 1999), Clariidae (Mansour et al., 2002), Siluridae (Emel'yanova \& Makeyeva, 1991b; Kwon et al., 1998; Lee \& Kim, 2001), Ictaluridae (Poirier \& Nicholson, 1982; Emel'yanova \& Makeyeva, 1991a), Heptapteridae and Pseudopimelodidae (Quagio-Grassiotto et al., 2005), Auchenipteridae (Burns et al., 2002), Pimelodidae (Quagio-Grassiotto \& Carvalho, 2000; Santos et al., 2001), and Bagridae (Emel'yanova \& Makeyeva, 1991b; Lee, 1998; Kim \& Lee, 2000; Mansour \& Lahnsteiner, 2003). The states "co-axial centrioles" (character 5) and "presence of electron-dense circular structure in the midpiece" (character 15) are observed only in Corydoradinae corroborating the monophyly of the subfamily.

\section{Acknowledgments}

We wish to thank R. Devidé, E. R. Miguel, M. C. C. de Pinna, M. R. Britto, C. K. Simabukuro-Dias, O. A. Shibatta, G. F. França, E. M. R. Martinez, P. C. Vênere, P. Gusmão-Pompiani, 
and M. C. Chiachio for their help during collection expeditions; M. R. Britto and R. E. Reis, for the taxonomic identification of the species, and the E. M. Laboratory of IBB-UNESP, for allowing the use of their facilities. This research was supported by the Brazilian agencies FAPESP (Fundação de Amparo à Pesquisa do Estado de São Paulo), and $\mathrm{CNPq}$ (Conselho Nacional de Desenvolvimento Científico e Tecnológico).

\section{Literature Cited}

Britto, M. R. 2003a. Análise filogenética da ordem Siluriformes com ênfase nas relações da superfamília Loricarioidea (Teleostei: Ostariophysi). Unpublished Ph.D. Thesis, Universidade Estadual de São Paulo, São Paulo, 512 p.

Britto, M. R. 2003b. Phylogeny of the subfamily Corydoradinae Hoedeman, 1952 (Siluriformes: Callichthyidae), with a definition of its genera. Proceedings of the Academy of Natural Science of Philadelphia, 153: 119-154.

Burns, J. R., A. D. Meisner, S. H. Weitzman \& L. R. Malabarba. 2002. Sperm and spermatozeugma ultrastructure in the inseminating catfish, Trachelyopterus lucenai (Ostariophysi: Siluriformes, Auchenipteridae). Copeia, 2002: 173-179.

Emel'yanova, N. G. \& A. P. Makeyeva. 1991a. Morphology of the gametes of the channel catfish Ictalurus punctatus. Voprosy Iktiologii, 31(1): 143-148.

Emel'yanova, N. G. \& A. P. Makeyeva. 1991b. Ultrastructure of spermatozoids of some representative catfishes. Journal of Ichthyology, 32: 127-134.

Kim, K. H. \& Y. H. Lee. 2000. The ultrastructure of spermatozoa of ussurian bullhead, Leiocassis ussuriensis (Teleostei, Siluriformes, Bagridae). Korean Journal of Limnology, 33(4): 405-412.

Kwon, A. S., K. H. Kim \& Y. H. Lee. 1998. Ultrastructure of spermatozoa in the catfish, Silurus asotus. Development and Reprodution, 2(1): 75-80.

Lahnsteiner, F. \& R. A. Patzner. 1990. Spermiogenesis and structure of mature spermatozoa in bleniid fishes (Pisces, Bleniidae). Journal of Submicroscopy Cytology and Pathology, 22: 565-576.

Lee, Y. H. 1998. Ultrastructure of spermatozoa in the bagrid catfish, Pseudobragrus fulvidraco (Teleostei, Siluriformes, Bagridae). Korean Society of Electron Microscopy, 28(1): 39-48.

Lee, Y. H. \& K. H. Kim. 1999. Ultrastructure of the south torrent catfish, Liobagrus mediadiposalis (Teleostei, Siluriformes, Amblycipitidae) spermatozoon. Korean Journal of Limnology, 32(3): 271-280.

Lee, Y. H. \& K. H. Kim. 2001. The ultrastructure of spermatozoa of the slender catfish, Silurus microdorsalis (Teleostei, Siluriformes, Siluridae). Journal of Submicroscopy Cytology and Pathology, 33(3): 329-336.

Mansour, N., F. Lahnsteiner \& R. A. Patzner. 2002. The spermatozoon of the African catfish: fine structure, motility, viability and its behavior in seminal vesicle secretion. Journal of Fish Biology, 60: 545-560.

Mansour, N. \& F. Lahnsteiner. 2003. Morphology of the male genitalia and sperm fine structure in siluroid fish. Journal of Submicroscopy Cytology and Pathology, 35(3): 277-285.

Mattei, X. 1970. Spermiogenése comparé des poisson. p. 57-72. In: Baccetti, B. (Ed.). Comparative Spermatology. Academic Press, New York.

Mattei, X. 1993. Peculiarities in the organization of testis of Ophidion sp. (Pisces: Teleostei). Evidence for two types of spermatogenesis in teleost fish. Journal of Fish Biology, 43: 931-937.

Muñoz, M., M. Casadevall \& S. Bonet. 2002. Testicular structure and semicystic spermatogenesis in a specialized ovuliparous species: Scorpaena notata (Pisces, Scorpaenidae). Acta Zoologica, 83: 213-219.

de Pinna, M. C. C. 1998. Phylogenetic relationship of neotropical Siluriformes (Teleostei: Ostariophysi): historical overviews and synthesis of hypotheses. Pp.279-330. In: Malabarba, L. R., R. E. Reis, R. P. Vari, Z. M. S. Lucena \& C. A. S. Lucena (Eds.). Phylogeny and Classification of Neotropical Fishes. Porto Alegre, Edipucrs. 603p.

Poirier, G. R. \& N. Nicholson. 1982. Fine structure of the testicular spermatozoa from the channel catfish, Ictalurus punctatus. Journal of Ultrastructural Research, 80: 104-110.

Quagio-Grassiotto, I. \& E. D. Carvalho. 2000. Ultrastructure of Sorubim lima (Teleostei, Siluriformes, Pimelodidae) spermiogenesis. Journal of Submicroscopy Cytology and Pathology, 32(4): 629-633.

Quagio-Grassiotto, I. \& C. Oliveira. 2007. (in press). Description of spermiogenesis and spermatozoa ultrastructure in Pimelodus maculatus and Pseudoplatystoma fasciatum (Siluriformes: Pimelodidae) showing the occurrence of a new type of spermiogenesis. Zoologischer Anzeiger.

Quagio-Grassiotto, I., C. Oliveira \& A. Gosztonyi. 2001. The ultrastructure of spermiogenesis and spermatozoa in Diplomystes mesembrinus. Journal of Fish Biology, 58: 1623-1632.

Quagio-Grassiotto, I., M. C. Gameiro, T. Schneider, L. R. Malabarba \& C. Oliveira. 2003. Spermiogensis and spermatozoa ultrastructure in five species of Curimatidae with some considerations on spermatozoa ultrastructure in the Characiformes. Neotropical Ichthyology, 1: 35-45.

Quagio-Grassiotto, I., M. A. Spadella, M. Carvalho \& C. Oliveira. 2005. Comparative description and discussion of spermiogenesis and spermatozoal ultrastructure in some species of Heptapteridae and Pseudopimelodidae (Telesotei: Siluriformes). Neotropical Ichthyology, 3(3): 403-412.

Reis, R. E. 1998. Anatomy and phylogenetic analysis of the neotropical callichthyid catfishes (Ostariophysi, Siluriformes). Zoological Journal of the Linnean Society, 124, 105-168.

Reis, R. E. 2003. Family Callichthyidae (armored catfishes). p. 291-309. In: Reis, R. E., S. O. Kullander \& C. J. Ferraris (Eds.) Check list of the freshwater fishes of South America. Porto Alegre: Edipucrs, 2003.

Reynolds, E. S. 1963. The use of lead citrate at high $\mathrm{pH}$ as an electron opaque stain in electron microscopy. Journal of Cell Biology, 17, 208-212.

Santos, J. E., N. Bazzoli, E. Rizzo \& G. B. Santos. 2001. Morphofunctional organization of the male reproductive system of the catfish Iheringichthys labrosus (Lütken, 1874) (Siluriformes: Pimelodidae). Tissue \& Cell, 33(5): 533-540.

Spadella, M. A., C. Oliveira \& I. Quagio-Grassiotto. 2006a. Occurrence of biflagellate spermatozoa in the Siluriformes families Cetopsidae, Aspredinidae, and Nematogenyidae (Teleostei: Ostariophysi). Zoomorphology, 125: 108-118.

Spadella, M. A., C. Oliveira \& I. Quagio-Grassiotto. 2006b. Spermiogenesis and introsperm ultrastructure of Scoloplax distolothrix (Ostariophysi: Siluriformes: Scoloplacidae). Acta Zoologica, 87: 341-48

Shimabukuro-Dias, C. K., C. Oliveira, R. E. Reis \& F. Foresti. 2004. Molecular phylogeny of the armored catfish family Callichthyidae (Ostariophysi, Siluriformes). Molecular Phylogenetics and Evolution, 32: 152 - 163.

Teugels, G. G. 1996. Taxonomy, phylogeny and biogeography of catfishes (Ostariophysi, Siluroidei); an overview. Aquatic Living Resource, 9: 9-34.

Submitted May 2006 Accepted June 2007 